\title{
LEAN PRACTICES AND BENEFITS: STUDY OF SRI LANKAN SMALL AND MEDIUM ENTERPRISES
}

\author{
R. Y. H. De Alwis Seneviratne, K. Dissanayake, S. P. Premaratna, \\ Nayani Melegoda, S. Ranwala, A. Fernando \\ University of Colombo \\ rajishtha@dbe.cmb.ac.lk
}

\begin{abstract}
Implementation of lean practices creates multiple benefits as depicted in literature. However, the experiences of implementing lean practices in manufacturing Small and Medium Enterprises (SMEs), in Sri Lanka, remain unexplored. Thus, the purpose of this study is to examine the extent to which manufacturing SMEs use lean practices and their accrued benefits. The study adopts survey method and uses a structured questionnaire looking into three areas; lean practices implemented, driving forces of lean implementation and the benefits experienced. Data is collected from 342 manufacturing SMEs located in the Western Province of Sri Lanka, selected adopting random sampling representing seven major sub-sects including clothing and textiles, food and beverages, electronics and computers, metals, petroleum, wood, leather, paper and construction. The study finds that Just-In-Time, 3P and Kanban/Kaizen/Pull systems are the commonly used lean practices. The implementation of lean practices in manufacturing SMEs are mainly driven by improved quality, customer demand for shorter lead time and competitive advantage in price and service experienced through the implementation. The main benefits experienced by the SMEs are customer satisfaction, improved corporate image, reduced waste and higher efficiency and productivity. In addition to these, reduced inventory levels, higher flexibility, reduced transportation lead time, reduced capacity surplus are revealed to be achieved more with lean practices. The findings of this study are beneficial for planning further investigations into the lean adaptation in the SME sector. This also has implications for SME owners as they
\end{abstract}


can be encouraged to implement lean practices and policy-making when promoting lean practices among SMEs.

Keywords: Benefits; Lean implementation; Lean practices; SMEs; Sri Lanka; Sustainability

\section{Introduction}

The current buzz word in Economics and business circles is sustainable development of economies and how businesses can contribute towards this cause. Lean practices are focused on creating more effective business by eliminating wasteful practices and improving efficiency. Lean practices also are an approach to develop and continuously improve production processes (Majava \& Ojanpera, 2017) and also address consumers expectation of better values when they purchase products (Bhamu \& Sangwan, 2014). Thus, SMEs implementing lean practices can contribute to achieving sustainable development of a country highlighting its importance to firms, economies, societies, and the environment (Premaratna et al. 2021).

SMEs in Sri Lanka account for a large portion of businesses (98.5 per cent of total industrial establishments are SMEs as per the Department of Census Survey and Statistics (2015)). Thus it is important that SMEs implement such practices. Given a major challenge faced by SMEs is how to compete with large firms who achieve cost efficiency by adopting lean practices. Lean practices enable a firm to be responsive to customer expectations and at the same time reduce costs and wastage throughout the supply chain (Bhamu \& Sangwan, 2014).

Many studies have (e.g., Kumar et al., 2006; Chen et al., 2010; Knol et al., 2018) been conducted in other parts of the globe on how lean practices are utilized by business, what determines the use of such practices and the perceived benefits of such practices and whether lean practices enhances such benefits. Such knowledge directs business practitioners and supporting agencies towards a broad understanding of the prevailing conditions and prospective needs of SMEs for their continuous improvement. However, Yadav et el. (2019) note that SMEs are often not studied when adoption of lean practices are concerned with most focus going to large enterprises or Western Europe (Alkhoraif et al., 2019). Further 
Knol et al., (2018) also argue the universality of findings of research done on lean practices in SMEs which stresses the importance of doing more research to find how in different contexts lean practices are being implemented and reap benefits where even Belhadi et al. (2018) recommend more research to be done on lean practices in SMEs. In the Sri Lankan context, there is dearth of research on the nature of the lean practices adopted by SMEs and the benefits experienced by those practices with limited research done limited to a particular sector (e.g. research on apparel exporters (Wickramasinghe \& Wickramasinghe, 2017). This vacuum in the knowledge has blocked practitioners' involvement in lean-based improvements in the SME sector. Thus, this study aims to examine the lean practices adopted by SMEs and the benefits of adopting lean practices in Sri Lanka.

The structure of this paper is as follows. It first presents a brief literature review on lean practices, followed by the methodology. Then it presents the analysis and concludes with limitations and suggestions for future research and implications for policy making.

\section{Literature Review}

The lean concept originated from Japanese manufacturing methods adopted in Toyota (Hu et al., 2015). Lean practices at Toyota can be traced back to its founders Sakichi Toyoda's automatic loom. The automatic automated work that used to be performed manually, and built the capability to make judgments into the machine itself. This eliminated defective products and waste, rapidly improving both productivity and work efficiency. Lean practices now have spread across the world (Toyota, n.d.).

Thus, Hu et al. (2015) argue that the lean idea involves operation concepts such as zero inventory, just in time, and small lot sizes, quality procedures such as Total Quality Management and total productive maintenance, and empowering employees.

Further, lean practices could also support the achievement of sustainable development. Sustainable Development Goals (SDGs) cover 17 diverse goals 
which include health, environmental preservation, and economic prosperity, and these goals are expected to be achieved in 2030. It has been observed that lean practices can contribute to achievement of these goals (Premaratna et al., 2021)

\subsection{Lean practices adopted in SMEs}

Literature has identified different types of lean practices used by SMEs. These include Value Stream Mapping (VSM)1(Belhadi et al., 2018; Kumar et al., 2006; Chen et al., 2010), Total Productive Maintenance (TPM2) (Gunasekaran \& Lyu. 1997), Gunasekaran, 1998; Kumar et al., 2006; Valente et al., 2019) 5S3 (Belhadi et al., 2018; Gunasekaran \& Lyu, 1997; Gunasekaran, 1998; Kumar et al., 2006; Rose et al., 2013) Kanban4. (Belhadi et al., 2018; Gunasekaran, 1998) Kaizen (continuous improvement) (Rose et al., 2013) Six Sigma (a set of techniques and tools for process improvement) (Kumar et al.,2006; Kumar et al., 2009; Thomas et al. 2009; Nabhani \& Shokri, 2009) just to name a few. Negrao et al. (2017) in their review of literature note that out of 38 articles reviewed the most common was Kaizen followed by Just-In-Time delivery, pull systems, cellular manufacturing, TPM, supplier development to name the top five. Other practices also include 5S, visual management, customer involvement, continuous flow, Single Minute Exchange of Die (SMED). In a study done in three European countries in the food manufacturing industry, it was noted that the implementation of lean practices was at initial stages (Dora et al. 2013) and SMEs have lower implementation of lean practices compared to larger enterprises (Shah \& Ward, 2003). Whether it is the same for a South Asian country is to be studied. 
1. Analyzing the current state and designing a future state for the series of events that take a product or service from the beginning of the specific process until it reaches the customer.

2. Method of physical asset management focused on maintaining and improving manufacturing machinery

3. Sort, Set in Order, Shine, Standardize, Sustain. These steps involve going through everything in a space, deciding what's necessary and what isn't, putting things in order, cleaning, and setting up procedures for performing these tasks on a regular basis

4. A scheduling system for lean manufacturing and just-in-time manufacturing 


\subsection{Critical success factors for lean implementation}

Several Critical Success Factors for lean adoption have been identified in literature. Employee involvement and participation is a commonly identified factor in studies such as Chin and Rafuse (1993), Kumar et al. (2009) and Panizzolo et al. (2012). The support from top management support and commitment have been identified by Chin and Rafuse (1993), Achanga et al. (2006), and Kumar et al. (2009), Panizzolo et al. (2012). In addition, training and education have been stressed in studies by Achanga et al. (2006), Kumar et al. (2009), and Dora et al. (2013). Organisational change (change in culture, strategy, vision and performance evaluation system) has been also stressed (Achanga et al., 2006; Kumar et al., 2006; Panizzolo et al., 2012; Dora et al., 2013). Financial capability (Achanga et al., 2006) and supply chain integration (Kumar et al., 2009) too have been identified as Critical Success Factors in adopting lean practices. It has also been argued that success of lean implementation is subjected to how resources are allocated and how the firms improve their competitive position in the supply chain (Hong \& Jeong, 2006).

Suppliers and buyers play a key role and the trust and commitment will help to successfully implement lean practices (Golicic \& Mentzer, 2006). If the customers and suppliers are not willing to change and be influenced, then the lean implementation may not be as successful (Golicic \& Medland, 2007) and that SMEs need to be in control of the practices. Skill level of employees, expertise available in the firm, and the culture of the firm determine successful implementation of lean practices (Dora et al., 2013). Along these lines Negrao et al. (2017) argue that changes in the treatment and behavior of people who are involved in the business is essential before, during and after implementation of lean practices. Knol et al. (2018) find that the factors for successful implementation vary based on the progression. They observed that in the initial stages of implementation lean practices could be improved by a 'bottom up manner' where factors such as learning focus, training and support become important. When however lean practices are more advanced top management support, supplier link, and a shared vision of improvement become important. 


\subsection{Benefits of lean practices in SMEs}

The benefits of implementing lean practices include improvement in operational performance in terms of productivity and quality (Dora et al. 2013), however country-of origin could create a difference (Dora et al., 2013). In a study of Dutch SMEs lean practices were found to contribute towards improving operational performance (Knol et al., 2018). In a case study of a North African SME by Belhadi et al. (2018) even noted that lean implementation impacts green performance. In a study of Portuguese SMEs by Valente et al. (2019) they concluded that lean practices improve market, financial and operational performance of SMEs.

-A review of literature by Ugochukwu et al, (2012) identifies the main benefits of implementing lean practices. These include low inventories, customer satisfaction, efficiency, quality, reduced cost and improved delivery, flexibility (flexibility in volume, product mix and delivery). In the review, they note that these benefits are linked to practices such as value chain analysis, waste elimination, system organisation, end-customer focus, problem solving and strong and effective relationships. Improved delivery can be realized by implementing practices such as TPM, and VSM. Supplier involvement is needed to achieve high quality specially in the early design stage and proper screening of suppliers is also needed. Flexibility can be achieved by using lean practices such as use of small lot sizes, supplier involvement, pull production and effective commination and information sharing. It is also argued that the benefits from lean practices arise in the long term (Alkhoraif et al., 2019: Negrao et al., 2017).

Babalola et al. (2019) identify three main clusters of benefits of lean practices as economic (cost, quality and time), social (relationship and satisfaction), and environment in relation to construction projects. Under economic benefits reduction in time and cost, improvement of quality, better inventory control and risk minimisation were some of the benefits identified. Under social employee satisfaction, employee health and safety, better cooperation among stakeholders were some of the benefits. Under environmental benefits, reduction of waste and attaining green construction were identified. 
It is also noted that in some cases there were reports of a negative impact of lean practices on performance. This is when environment is not conducive for implementation of lean practices, where the culture negatively influences the effect lean practices have on the performance of the business (Negrao et al., 2017)

\subsection{Lean practices in SMEs in Sri Lanka}

When it comes to the Sri Lankan context there was a study done on BOI registered firms which export most of their output (90\%) and had a workforce from 300 to 5000. The waste minimisation, defect minimsation, cross-functional teams, continuous improvement, JIT, and pull, information and employee involvement as a bundle of lean production practices. These practices when simultaneously implemented positively affect production outcomes (Wickrama singhe \& Wickramasinghe, 2017). Even $\mathrm{Hu}$ et al. (2015) in their review of literature that there is inadequate research done on lean practices in SMEs. Based on the above studies it could be seen that hardly any research has been done on lean practices in SMEs in Sri Lanka. There is a lack of studies done on what are the lean practices in Sri Lanka and how they benefit SMEs in Sri Lanka.

\section{Methodology}

This study follows a sample survey with 342 SMEs in the Western Province in Sri Lanka was conducted under the World Bank project namely, 'green adoption of SMEs in Sri Lanka. Face to face interviews were carried out from May to September, 2019 with SME owners and managers. The sample was based on a random selection from the manufacturing SME list prepared by the research team based on the information collected from the Chamber of Commerce, Ministry of SME Development, Department of Census and Statistics in Sri Lanka as there is no single list readily available about SMEs in Sri Lanka. The lean practices covered in this study were 5S, Kanban Kaizen/Pull system, 3P (production process preparation), Total Productive Maintenance (TPM), Just-in-Time, Six Sigma, and Value Stream Mapping (VSM). Thus, the SMEs were asked whether they had such a practice or not. Data was also collected as to what drove SMEs to implement lean practices. These include pressure that could come from customers, competitive 
advantage, supply chain and government regulations as identified in literature. The respondents were asked whether customers demand for shorter lead times, pressure to efficiently consume resources, supply chain capacity reduction, competitive advantage in price and service, government regulations, customer demand for production flexibility, improved inventory turns, and improved quality of products drove the SMEs to implement lean practices or not.

Benefits such as increased customer satisfaction/ loyalty, improved corporate image, reduced waste throughout the supply chain, higher efficiency and productivity, reduced production lead time, reduced inventory levels, higher flexibility, reduced environmental incidents, reduced overall costs, reduced capacity surplus, increased energy and water savings, reduced transportation lead time were also asked based on a five point Likert scale.

The benefits would be then compared between SMEs who had implemented a lean practice and not implemented a lean practice using independent $t$ sample test and Levene's test for equality of variances (Derrick et al., 2017)

\section{Findings}

\subsection{Sample characteristics}

The sample of 342 SMEs in the manufacturing sector were from different sectors and the details are shown in Table 1.

Table 1: Sectors of the SMEs in the Sample

\begin{tabular}{ll}
\hline Sector & Number of SMEs (\%) \\
\hline Clothing and Textiles & $50(14.6 \%)$ \\
Food and Beverage & $48(14 \%)$ \\
Metals & $52(15.2 \%)$ \\
Petroleum, Chemicals and Plastics & $30(8.8 \%)$ \\
Electronics and Computers & $30(8.8 \%)$ \\
Wood, leather, and paper & $70(20.5 \%)$ \\
Construction & $36(10.5 \%)$ \\
Others & $26(7.6 \%)$ \\
\hline
\end{tabular}


Based on the above most of the sample represented wood, leather and paper (20.5 percent) followed by metals (15.2 per cent) and then clothing and textiles (14.6 percent). The average turnover of the firms during the past three years was Rs. 88 million while expenses are Rs. 57 million.

\subsection{Lean practices}

The respondents were asked what lean practices they adopted. The commonly implemented lean practices included Just-in-Time (61.7 per cent), 3P (42.1 per cent) and Kanban/Kaizen/Pull systems (33.6 per cent). Further details are shown in Table 2

Table 2: Lean Practices Implemented in SMEs

\begin{tabular}{lll}
\hline Practice & Yes & No \\
\hline 5S & $69(20.2 \%)$ & $273(79.8 \%)$ \\
Kanban Kaizen/Pull & $115(33.6 \%)$ & $227(66.4 \%)$ \\
3P Production Process Preparation & $144(42.1 \%)$ & $198(57.9 \%)$ \\
Total Productive Maintenance & $31(9.1 \%)$ & $311(90.9 \%)$ \\
Just-in-Time & $211(61.7 \%)$ & $130(38.3 \%)$ \\
Six Sigma & $72 \%$ & $335(98 \%)$ \\
Value Stream Mapping & $32(9.4 \%)$ & $310(90.6 \%)$ \\
\hline
\end{tabular}

In terms of the duration that the SMEs used lean practices, 18 out of 87 respondents stated that they have used lean practices for 10 years while 16 have used lean practices for 5 years. Twenty-eight respondents have been using lean practices for 12 months or less. The mean number of months is 52 which translates to 4 years and four months. Thus it appears that in Sri Lanka lean practices are in its early stages. 
When looking at the factors that drive SMEs to lean practices, 8 factors were identified details of which are shown in Table 3.

Table 3: Factors that drive the SMEs to become Lean

\begin{tabular}{lll} 
Driving towards lean & Yes & No \\
\hline Customers demand for shorter lead times & $187(54.7 \%)$ & $155(45.3 \%)$ \\
$\begin{array}{l}\text { Pressure to efficiently consume resources for supply } \\
123(36 \%)\end{array}$ & $219(64 \%)$ \\
chain capacity reduction & & \\
Competitive advantage in price and service & $180(52.6 \%)$ & $162(47.4 \%)$ \\
Government regulations & $63(18.4 \%)$ & $279(81.6 \%)$ \\
Customers demand for production flexibility & $175(51.2 \%)$ & $167(48.8 \%)$ \\
Improved inventory turns & $45(13.2 \%)$ & $297(86.8 \%)$ \\
Improved quality of products & $292(85.4 \%)$ & $50(14.6 \%)$ \\
\hline
\end{tabular}

Based on the above it is observed that the 3 main commonly stated factors that drove the SMEs to be lean are improved quality (85.4 per cent), customer demand for shorter lead time (54.7 per cent) and competitive advantage in price and service (52.6 per cent).

The SMEs were asked what the benefits they experienced with lean practices. The main benefits with the highest mean values were customer satisfaction (3.57), improved image (3.47), reduced waste (3.4), and higher efficiency and productivity (3.36). These results also imply that the experienced benefits of lean practices are more of outward-focused rather than inward. The results are shown in Table 4 below.

\section{Table 4: Benefits of Lean Practices}

\begin{tabular}{lll}
\hline Benefit & Mean & Standard Deviation \\
\hline Increased customer satisfaction and loyalty & 3.57 & 0.563 \\
Improved corporate image & 3.47 & 0.63 \\
Reduced waste throughout the supply chain & 3.4 & 0.632 \\
Higher efficiency and productivity & 3.36 & 0.651 \\
Reduced production lead time & 3.32 & 0.69
\end{tabular}


Reduced inventory levels

Higher flexibility

Reduced environmental incidents

Reduced overall costs

Reduced capacity surplus

Increased energy and water savings

Reduced transportation lead time

Other
$3.29 \quad 0.719$

$3.28 \quad 0.556$

$3.25 \quad 0.676$

$3.21 \quad 0.729$

$3.13 \quad 0.631$

$3.11 \quad 0.588$

$3.09 \quad 0.644$

$2.06 \quad 0.305$

The SMEs were asked what were the key factors for successful implementation of lean practices. The results of it are shown in Table 5 below.

\section{Table 5: Key Factors for Successful Implementation of Lean Practices}

\begin{tabular}{lll}
\hline Key Factors to successful implementation of lean manufacturing & Mean & StdDev \\
\hline Product quality and design & 3.69 & 0.614 \\
Reliable and efficient equipment and infrastructure & 3.59 & 0.543 \\
Standardization of work processes & 3.5 & 0.675 \\
Effectiveness & 3.44 & 0.66 \\
Steady material flow & 3.44 & 0.559 \\
Customers & 3.33 & 0.639 \\
Safety & 3.33 & 0.551 \\
Management and culture & 3.31 & 0.576 \\
Flexibility (system/production process) & 3.25 & 0.58 \\
Low inventory levels & 3.24 & 0.711 \\
Suppliers & 3.23 & 0.577 \\
Lean tools and techniques & 3.14 & 0.566 \\
Employees & 3.06 & 0.61 \\
Government basic requirement only & 1.98 & 0.939 \\
\hline
\end{tabular}

Based on the analysis shown on Table 5 above, the three key factors for successful implementation of lean practices are product quality and design (3.69), reliable and efficient equipment and infrastructure (3.59) and standardization of work processes (3.5).

Given the lean practice that was used most was Just-In-Time, the benefits of lean practices were compared between firms that had implemented Just-In-Time with those who had not. The results are shown below. 
Table 6: Means of Benefits

\begin{tabular}{|c|c|c|c|}
\hline $\begin{array}{l}\text { Benefit of Lean } \\
\text { Practice }\end{array}$ & $\begin{array}{l}\text { Lean practices adopted- } \\
\text { Just-in-Time } \\
\text { Production }\end{array}$ & Mean & $\begin{array}{c}\text { Std. } \\
\text { Deviation }\end{array}$ \\
\hline \multirow{2}{*}{$\begin{array}{l}\text { Higher efficiency and } \\
\text { productivity }\end{array}$} & Yes & 3.34 & .667 \\
\hline & No & 3.38 & .627 \\
\hline \multirow{2}{*}{$\begin{array}{l}\text { Reduced inventory } \\
\text { levels }\end{array}$} & Yes & 3.35 & .676 \\
\hline & No & 3.18 & .775 \\
\hline \multirow{2}{*}{$\begin{array}{l}\text { Reduced environmental } \\
\text { incidents }\end{array}$} & Yes & 3.23 & .687 \\
\hline & No & 3.28 & .659 \\
\hline \multirow{2}{*}{$\begin{array}{l}\text { Reduced waste } \\
\text { throughout the supply } \\
\text { chain }\end{array}$} & Yes & 3.39 & .649 \\
\hline & No & 3.41 & .606 \\
\hline \multirow{2}{*}{$\begin{array}{l}\text { Increased customer } \\
\text { satisfaction/ loyalty }\end{array}$} & Yes & 3.61 & .561 \\
\hline & No & 3.50 & .560 \\
\hline \multirow{2}{*}{$\begin{array}{l}\text { Increased energy and } \\
\text { water savings }\end{array}$} & Yes & 3.12 & .617 \\
\hline & No & 3.10 & .541 \\
\hline \multirow{2}{*}{ Higher flexibility } & Yes & 3.33 & .597 \\
\hline & No & 3.21 & .477 \\
\hline \multirow[t]{2}{*}{ Reduced overall costs } & Yes & 3.13 & .744 \\
\hline & No & 3.35 & .690 \\
\hline \multirow{2}{*}{$\begin{array}{l}\text { Reduced production } \\
\text { lead time }\end{array}$} & Yes & 3.28 & .719 \\
\hline & No & 3.38 & .640 \\
\hline \multirow{2}{*}{$\begin{array}{l}\text { Reduced transportation } \\
\text { lead time }\end{array}$} & Yes & 3.15 & .627 \\
\hline & No & 2.99 & .665 \\
\hline \multirow{2}{*}{$\begin{array}{l}\text { Reduced capacity } \\
\text { surplus }\end{array}$} & Yes & 3.21 & .658 \\
\hline & No & 2.99 & .564 \\
\hline $\begin{array}{l}\text { Improved corporate } \\
\text { image }\end{array}$ & $\begin{array}{l}\text { Yes } \\
\text { No }\end{array}$ & $\begin{array}{l}3.52 \\
3.39\end{array}$ & $\begin{array}{l}.664 \\
.564\end{array}$ \\
\hline
\end{tabular}

Based on the above in almost all the benefits there was a higher mean value with Just-In-Time system in place. The means were then compared using Levene's test and the $t$ test. The results are shown on table 7 below. 
Table 7: Independent Samples Test

\begin{tabular}{|c|c|c|c|}
\hline Benefit & $\begin{array}{l}\text { Levene's Test } \\
\text { (sig) }\end{array}$ & $\begin{array}{l}\text { T Stat } \\
\text { (sig) }\end{array}$ & Mean Difference \\
\hline $\begin{array}{l}\text { Higher efficiency and } \\
\text { productivity }\end{array}$ & $\begin{array}{l}0.234 \\
(0.629) \\
\end{array}$ & $\begin{array}{l}-0.597 \\
(0.551) \\
\end{array}$ & -.043 \\
\hline Reduced inventory levels & $\begin{array}{l}2.832 \\
(0.093) \\
\end{array}$ & $\begin{array}{l}2.082 \\
(0.038)\end{array}$ & .166 \\
\hline $\begin{array}{l}\text { Reduced environmental } \\
\text { incidents }\end{array}$ & $\begin{array}{l}0.494 \\
(0.482)\end{array}$ & $\begin{array}{l}-0.655 \\
(0.513) \\
\end{array}$ & -.049 \\
\hline $\begin{array}{l}\text { Reduced waste throughout the } \\
\text { supply chain }\end{array}$ & $\begin{array}{l}1.307 \\
(0.254)\end{array}$ & $\begin{array}{l}-0.203 \\
(0.839) \\
\end{array}$ & -.014 \\
\hline $\begin{array}{l}\text { Increased customer } \\
\text { satisfaction/ loyalty }\end{array}$ & $\begin{array}{l}0.993 \\
(0.320) \\
\end{array}$ & $\begin{array}{l}1.781 \\
(0.076) \\
\end{array}$ & .111 \\
\hline \multirow[t]{2}{*}{$\begin{array}{l}\text { Increased energy and water } \\
\text { savings }\end{array}$} & $\begin{array}{l}4.468 \\
(0.035) \\
\end{array}$ & $\begin{array}{l}0.281 \\
(0.779)\end{array}$ & .018 \\
\hline & & $\begin{array}{l}0.290 \\
(0.772)\end{array}$ & .018 \\
\hline \multirow[t]{2}{*}{ Higher flexibility } & $\begin{array}{l}25.057 \\
(0.000) \\
\end{array}$ & $\begin{array}{l}2.007 \\
(0.046) \\
\end{array}$ & .124 \\
\hline & & $\begin{array}{l}2.115 \\
(0.035) \\
\end{array}$ & .124 \\
\hline Reduced overall costs & $\begin{array}{l}0.015 \\
(0.903) \\
\end{array}$ & $\begin{array}{l}-2.644 \\
(0.009) \\
\end{array}$ & -.213 \\
\hline Reduced production lead time & $\begin{array}{l}1.650 \\
(0.200) \\
\end{array}$ & $\begin{array}{l}-1.365 \\
(0.173) \\
\end{array}$ & -.105 \\
\hline
\end{tabular}




\begin{tabular}{|l|l|l|l|}
\hline $\begin{array}{l}\text { Reduced transportation lead } \\
\text { time }\end{array}$ & 5.405 & $\begin{array}{l}2.162 \\
(0.021)\end{array}$ & .155 \\
\cline { 2 - 4 } & & $\begin{array}{l}2.031) \\
\end{array}$ & \\
\hline Reduced capacity surplus & 25.843 & $(0.034)$ & \\
& $(0.000)$ & $(0.002)$ & .155 \\
\cline { 2 - 4 } & & 3.225 & .216 \\
& & $(0.001)$ & \\
\hline Improved corporate image & 5.316 & 1.775 & .124 \\
& $(0.022)$ & $(0.077)$ & \\
\cline { 2 - 4 } & & 1.845 & .124 \\
& & $(0.066)$ & \\
\hline
\end{tabular}

It appears that firms which implemented Just-In-Time practice experienced significantly higher benefits (95\% confidence) in reduced inventory levels, higher flexibility, reduced transportation lead time, and reduced capacity surplus. These findings are indeed supported by many studies (e.g., Dora et al., 2013: Knol et al., 2018) which argue that lean practices improve performance of SMEs. The above can be explained by the study of Singh et al. (2010) who noted that the implementation of Just-In-Time reduced the lead time, the processing time, reduced the work in progress inventory and also reduced the requirement for man power where the productivity per operator also rose. Ugochukwu et al. (2012) also argued that implementation of lean practices such as Just-In-Time and pull production, cost of holding inventory is reduced as inventory accumulation is minimised. Further, lead time is also reduced as unnecessary processes are avoided. Benefits are further achieved by waste elimination, avoiding over production, unwanted transportation, stock piling and processing activities. As the focus is on the customer, the entire value chain is driven towards reducing waste and adding value and hence customers are also satisfied. However, it is also found that overall cost is higher with Just-In-Time. This could be due to the lack of a conducive environment and given that benefits are more in the long term, it might 
take time for this to be realized (Alkoraif et al., 2019; Negrao et al., 2017). Thus the benefits could be experienced more in the long term.

\section{Conclusion}

This study was conducted based on survey of 342 SMEs in the Western Province of Sri Lanka to identify what are the lean practices implemented in SMEs and the benefits from such practices. The lean practices examined in this study are all with foreign origin. They have been introduced to Sri Lankan enterprises, educated and inculcated into the existing practices. Thus, we understand that non-indigenous practices, which are learnt from diverse external contexts can be internalized into the local SME sector. Irrespective of the origin, good practices can be convinced and informed to the communities involved in SMEs, however, proper education and training would be the prime mover. It was observed that the commonly adopted lean practice was Just In Time. The three main commonly stated factors that drove the SMEs to be lean are, improved quality, customer demand for shorter lead time and competitive advantage in price and service.The main benefits with the highest mean values were customer satisfaction, improved image, reduced waste, and higher efficiency and productivity.

Implementing practices such as Just In Time gave greater benefits compared to not implementing in benefits such as reduced inventory higher flexibility reduced transportation lead time reduced capacity surplus based on the analysis it can be concluded that lean practices amongst SMEs in Sri Lanka need to be further improved. Many SMEs have implemented lean practices recently with most of them having had practices for a short term. It is a long-term process and gradual improvement of organisational processes and thus SME owners need to be encouraged to have a long-term view (Alkhoraif et al., 2019). As evidenced in the findings of this study, lean practices in SMEs seemed to be encouraged by pull factors which are emanating from the external environment. However, the theoretical logic behind the primary use of lean practices is an internal drive towards achieving efficiencies which could lead to gaining competitive advantage in the long-run. Therefore, educating SME owners on the internally achievable benefits of implementing lean practices seem to be the need in this 
context. In addition to this, the regulatory involvement in promoting lean practices would be another need as implied in the study.

Limitations of this study include the fact that relationships were not identified and a model was not developed, as the intention of this study was to identify what the practices were and what SMEs experienced as benefits. This could be further expanded in subsequent research to develop a model for SMEs usage of lean practices. Further studies could be done on cases of SMEs that had implemented lean practices to identify why and how they implemented lean practices and get an in-depth understanding of the challenges they faced and how they were overcome.

This research was supported by the Accelerating Higher Education Expansion and Development (AHEAD) Operation of the Ministry of Higher Education, Sri Lanka, funded by the World Bank 


\section{References :}

Achanga, P., Shehab, E., Roy, R., \&Nelder, G. (2006). Critical success factors for lean implementation within SMEs. Journal of Manufacturing Technology Management, 17(4), 460-471.

Alkhoraif, A., Rashid, H., \& McLaughlin, P. (2019), Lean implementation in small and medium enterprises: Literature review. Operations Research Perspectives, 6, https://doi.org/10.1016/j.orp.2018.100089

Babalola, O., Ibem, E. O., \&Ezema, I. C. (2019). Implementation of lean practices in the construction industry: A systematic review. Building and Environment, 148, 34-43. https://doi.org/10.1016/j.buildenv.2018.10.051

Belhadi,A., Touriki, F. E., El Fezazi, S. (2018). Benefits of adopting lean production on green performance of SMEs: A case study. Production Planning \& Control, 29(11), 873-894

Bhamu, J., \&Sangwan, K. S. (2014). Lean manufacturing: Literature review and research issues. International Journal of Operations \& Production Management, 34(7), 876-940.

Chen, J. C., Li, Y., \& Shady, B. D. (2010). From value stream mapping toward a lean/sigma continuous improvement process: An industrial case study. International Journal of Production Research, 48(4), 1069-1086.

Chin, L., \&Rafuse, B. A. (1993). A small manufacturer adds JIT techniques to MRP. Production and Inventory Management Journal, 34(4), 18-22.

Department of Census and Statistics Sri Lanka. (2015). Key indicators of industry trade and services. http://www.statistics.gov.lk/PressReleases/Files/en/ EC_20150714E.pdf

Derrick, B., Russ, B., Toher, D., \& White, P. (2017). Test statistics for the comparison of means for two samples that include both paired and independent observations. Journal of Modern Applied Statistical Methods, 16(1), 137-157 
Dora, M., Kumar, M., Goubergen, D. V., Molnar, A., \&Gellynck, X. (2013). Operational performance and critical success factors of Lean manufacturing in European food processing SMEs. Trends in Food Science \& Technology, $31(2), 156-164$.

Gunasekaran, A. C. (1998). Experiences of a small company in productivity improvements. Production and Inventory Management Journal, 39(2), $49-54$.

Gunasekaran, A., \&Lyu, J. (1997). Implementation of just-in-time in a small company. Production Planning and Control, 8(4), 406-412.

Hong, P. C, \&Jeong, J. (2006). Supply chain management practices of SMEs: From a business growth perspective. Journal of Enterprise Information Management, 19(3), 292-302

Hu, Q., Mason, R., Williams, S. J., Found, P. (2015). Lean implementation within SMEs: A literature review. Journal of Manufactuing Technology Management, 26(7), 980-1012

Knol, W. H., Slomp, J., Schouteten, R. L. J., \& Lauche, K. (2018). Implementing lean practices in manufacturing SMEs: Testing cirtical success factors using necessary condition analysis. International Journal of Production Research, 56(11), 3955-3973

Kumar, M., Antony, J., \& Douglas, A. (2009). Does size matter for six sigma implementation? Findings from the survey in UK SMEs. The TQM Journal, 21(6), 623-635.

Kumar, M., Antony, J., Singh, R. K., Tiwari, M. K., \& Perry, D. (2006). Implementing the lean sigma framework in an Indian SME: a case study. Production Planning \& Control, 17(4), 407-423

Majaval, J., Ojanper, T. (2017). Lean production development in SMEs: A case study. Management and Production Engineering, 8(2), 41-48 
Nabhani, F., \&Shokri, A. (2009). Reducing the delivery lead time in a food distribution SME through the implementation of six sigma methodology. Journal of Manufacturing Technology Management, 20(7), 957-974.

Negrao, L. L. L., Filho, M. G., \&Marodin, G. (2017). Lean practicesand their effect on perfmorance: A literature review. Produciton Planning \& Control, 28(1), 33-56. https://doi.org/10.1080/09537287.2016.1231853

Panizzolo, R., Garengo, P., Sharma, M., \& Gore, A. (2012). Lean manufacturing in developing countries: Evidence from Indian SMEs. Production Planning \& Control,23(10-11), 769-788.

Premaratna, S. P., De AlwisSeneviratne, R. Y. H., Dissanayake, K. D., Ranwala, S., Melegoda, N., Fernando, A. (2021). Drivers of lean manufacturing practices in Sri Lankan SMEs: A preliminary result (University of Colombo Faculty of Graduate Studies (Working Paper No. 2). Faculty of Graduate Studies, University of Colombo

Rose, A. N. M., Deros, B., \& Rahman, M. N. (2013). Lean manufacturing perceptions and actual practice among Malaysian SMEs in automotive industry. International Journal of Automotive and Mechanical Engineering, $7,820-829$

Shah, R., \& Ward, P. T. (2003). Lean manufacturing: Context, practice bundles, and performance.Journal of Operations Management, 21(2), 129-149.

Singh, B., Garg, S. K., Sharma, S. K., \& Grewal, C. (2010). Lean implementation and its benefits to production industry. International Journal of Lean Six Sigma, 1(2), 157-168. DOI 10.1108/20401461011049520

Thomas, A., Barton, R., \&Chuke-Okafor, C. (2009). Applying lean six sigma in a small engineering company-Amodel for change. Journal of Manufacturing Technology Management, 20(1), 113-129

Toyota (n.d.). Toyota production system. https://global.toyota/en/company/ vision-and-philosophy/production-system/ 
Ugochukwu, P, Engstrom, J., \&Langstrand, J. (2012). Lean in the supply chain: A literature review. Management and Production Engineering Review, 3(4), 87 - 96. DOI:10.2478/v10270-012-0037-6

Valente, C. M., Sousa, P. S. A., Moreira, M. R. A. (2019). Assessment of the lean effect on business performance: The case of manufacturing SMEs. Journal of Manufacturing Technology Management, 31(3), 501-523

Wickremasinghe, G. L. D., \&Wickramasinghe, V. (2017). Implementation of lean production practices and manufacturing performance The role of lean duration. Journal of Manufacturing Technology Management 28(4), 531-550. DOI 10.1108/JMTM-08-2016-011

Yadav, V., Jain, R., Mittal, M. L., Panwar, A., Lyons, A. C. (2019). Propagation of lean thinking in SMEs. Production Planning \& Control, 30(10-12), $854-865$. 